\title{
Impact of Weather Factors on Development of Red Rot Disease of Sugarcane Agro-Ecosystem
}

\author{
Sudhir Paswan ${ }^{*}$, Md. Minnatullah ${ }^{2}$, Mahesh Kumar $^{3}$ and Abdus Sattar \\ ${ }^{1}$ Department of Statistics, SRI, DRPCAU, Pusa, Bihar - 848125, India \\ ${ }^{2}$ Department of Plant pathology, SRI, DRPCAU, Pusa, Bihar-848125, India \\ ${ }^{3}$ Faculty of BS\&H, DRPCAU, Pusa, Bihar - 848125, India \\ ${ }^{4}$ Department of Meteorology, DRPCAU, Pusa, Bihar - 848125, India
}

*Corresponding author

\begin{tabular}{|l|}
\hline Key w or d s \\
$\begin{array}{l}\text { Sugarcane, Red rot, } \\
\text { Disease and } \\
\text { Weather factors }\end{array}$ \\
\hline Article Info \\
\hline $\begin{array}{l}\text { Accepted: } \\
\text { 04 January } 2018 \\
\text { Available Online: } \\
\text { 10 February } 2018\end{array}$ \\
\hline
\end{tabular}

A B S T R A C T

The model of forewarning about the infection of red rot disease in sugarcane was studied and observations were recorded at fortnight interval starting from June upto December during each year of experimentation. The maximum infection was recorded during $2^{\text {nd }}$ fortnight of July while minimum $(1.4 \%)$ was at $1^{\text {st }}$ fortnight of June. Using the original data on the response variable i.e. infection of red rot disease, the simple linear regression model was fitted with fortnightly as explanatory variable and describe the severity of the infection of red rot disease during the fortnight. The value of multiple correlations for red rot disease was 0.7159 . We also include meteorological factors i.e. maximum temperature, minimum temperature $\left({ }^{0} \mathrm{C}\right.$ ), relative humidity percentage (at $7.00 \mathrm{hrs}$ and $14.00 \mathrm{hrs}$ ) and sunshine hours in the model. This model provides the severity of infection of the above mentioned disease forewarning. Meteorological factors played an important role in seasonal infection, distribution and disease build up. It is difficult to give a direct cause and effect relationship between any single factor and disease incidence because the impact of meteorological factors is usually compounded.

\section{Introduction}

Sugarcane (Saccharum sp. Hybrid) is one of the major tropical $\mathrm{C} 4$ plant that is cultivated in the tropical and subtropical regions globally and contributes to $75 \%$ of the world's sugar (Singh et al., 2011). It contributes nearly 70 percent of world sugar production and provides raw material for many other by products (Gawade et al., 2012). Among the various factors lowering down the production and productivity of sugarcane, the prevalence and infection of disease are one of them. About 100 diseases of sugarcane caused by fungi, bacteria, virus and phytoplasma have been reported from different parts of the world, out of which 55 diseases reported from India (Rott et al., 2000) and 25 diseases from Bihar.

Among the various diseases affecting sugarcane, the red rot disease is a major constraint for sugarcane production. In India and the subcontinent faced many epidemics in 
the past resulting in elimination of many popular varieties from cultivation (Viswanathan, 2010). Diseases are the major factors for reduction in crop yield of sugarcane, among them red rot disease is major concern and it causes the losses of 1025 per cent to the sugarcane crop (Mohanraj et al., 2003). In severe infection whole crop may be destroyed. The affected canes recorded 25$75 \%$ reduced sucrose content than the healthy canes (Viswanathan and Samiyappan, 1999). If information about time, severity and outbreak of disease are available in advance, timely control measures can be taken up so losses may be reduced. Weather plays an important role in disease development. Therefore, weather based models can be an effective scientific tool for forewarning diseases in advance. Forewarning of disease is important for crop production management and taking timely plant protection measures. Information of whether and disease status is expected to be below or above the threshold level is used for models building. Ramasubramaniun et al., (2006) developed statistical models for forewarning about infestation of paddy crops using step-wise regression technique and weather indices modeling technique without using transformation of data.

\section{Materials and Methods}

To assess the impact of different weather parameters i.e. temperature $\left({ }^{0} \mathrm{C}\right)$, relative humidity (\%), rainfall (mm), sunshine (hrs.) on the development of red rot disease incidence in sugarcane crop. The observations on red rot incidence were recorded through an extensive survey conducted over eleven years (2006-16) at fortnightly interval on clump basis. The incidence was calculated on plot basis irrespective of number of clumps showing infection in the plot. The per cent incidence of disease was worked out by using formula.
Per cent red rot infection = No.of infected clumps $X 100$

Total no, of clumps

\section{Statistical analysis}

Weather data collected from department of Agro-meteorology, DRPCAU, Pusa, Samastipur was subjected to correlation and regression analysis with disease incidence.

The following statistical model was used to assess the impact of weather factors on disease incidence.

$Y=a+b_{1} x_{1}+b_{2} x_{2}+b_{3} x_{3}+b_{4} x_{4}+b_{5} x_{5}+b_{6} x_{6}$

Where,

$\mathrm{Y}=$ Dependent variable (Disease incidence)

$\mathrm{a}=$ Pure constant

$b_{1}=$ Regression coefficient for maximum temperature $\left(\mathrm{X}_{1}\right)$

$b_{2}=$ Regression coefficient for minimum temperature $\left(\mathrm{X}_{2}\right)$

$\mathrm{b}_{3}=$ Regression coefficient for $\mathrm{RH}$ at $7 \mathrm{hrs}$. $\left(\mathrm{X}_{3}\right)$

$\mathrm{b}_{4}=$ Regression coefficient for $\mathrm{RH}$ at $14 \mathrm{hrs}$. $\left(\mathrm{X}_{4}\right)$

$b_{5}=$ Regression coefficient for rainfall $\left(X_{5}\right)$

$\mathrm{b}_{6}=$ Regression coefficient for sunshine $\left(\mathrm{X}_{6}\right)$

\section{Results and Discussion}

The data of disease incidence is presented in table 1, reflected that the disease appeared on the crop appeared in $1^{\text {st }}$ fortnight of June up to $2^{\text {nd }}$ fortnight of December during course of investigation. 
Table.1 Means of observations on explanatory variable for eleven (11) years (2006 to 2016)

\begin{tabular}{|c|c|c|c|c|c|c|c|c|}
\hline \multirow[t]{2}{*}{ Months } & \multirow[t]{2}{*}{ Fortnight } & \multirow{2}{*}{$\begin{array}{c}\text { Disease } \\
\text { incidence } \\
(\%)\end{array}$} & \multicolumn{2}{|c|}{ Temperature $\left({ }^{0} \mathrm{C}\right)$} & \multicolumn{2}{|c|}{ Relative humidity (\%) } & \multirow{2}{*}{$\begin{array}{c}\text { Rainfall } \\
(\mathrm{mm}) \\
(\mathrm{X5})\end{array}$} & \multirow{2}{*}{$\begin{array}{c}\text { Sunshine } \\
\text { (hrs) } \\
\text { (X6) }\end{array}$} \\
\hline & & & $\begin{array}{r}\text { Max } \\
\text { (X1) }\end{array}$ & $\begin{array}{l}\text { Min. } \\
\text { (X2) }\end{array}$ & $\begin{array}{c}7.00 \text { hrs } \\
\text { (X3) }\end{array}$ & $\begin{array}{c}14.00 \mathrm{hrs} \\
(\mathrm{X} 4)\end{array}$ & & \\
\hline \multirow{2}{*}{ January } & I & 0.0 & 19.7 & 8.4 & 90.2 & 59.4 & 5.1 & 3.6 \\
\hline & II & 0.0 & 10.0 & 8.9 & 91.0 & 57.5 & 2.8 & 4.3 \\
\hline \multirow[t]{2}{*}{ February } & I & 0.0 & 23.2 & 9.7 & 87.8 & 52.3 & 0.7 & 5.9 \\
\hline & II & 0.0 & 25.3 & 12.3 & 86.6 & 52.3 & 8.6 & 6.3 \\
\hline \multirow[t]{2}{*}{ March } & I & 0.0 & 28.3 & 13.5 & 83.1 & 47.1 & 4.1 & 7.2 \\
\hline & II & 0.0 & 31.5 & 15.7 & 82.4 & 39.6 & 0.8 & 7.9 \\
\hline \multirow[t]{2}{*}{$\overline{\text { April }}$} & I & 0.0 & 35.5 & 18.7 & 77.2 & 36.7 & 6.1 & 7.9 \\
\hline & II & 0.0 & 36.2 & 21.2 & 72.7 & 36.8 & 7.6 & 8.0 \\
\hline \multirow[t]{2}{*}{ May } & I & 0.0 & 36.7 & 23.1 & 74.7 & 42.7 & 9.4 & 8.2 \\
\hline & II & 0.0 & 36.7 & 24.2 & 74.8 & 43.5 & 68.6 & 8.7 \\
\hline \multirow[t]{2}{*}{ June } & I & 1.4 & 35.4 & 25.2 & 82.7 & 54.6 & 50.3 & 7.5 \\
\hline & II & 3.2 & 35.8 & 26.5 & 83.6 & 58.5 & 54.7 & 7.3 \\
\hline \multirow[t]{2}{*}{ July } & I & 12.5 & 34.4 & 26.8 & 86.7 & 66.7 & 93.6 & 4.9 \\
\hline & II & 15.6 & 33.3 & 26.8 & 88.1 & 70.4 & 135.8 & 4.8 \\
\hline \multirow[t]{2}{*}{ August } & I & 9.2 & 32.7 & 26.4 & 91.1 & 73.8 & 138.7 & 5.9 \\
\hline & II & 13.5 & 33.5 & 26.8 & 89.2 & 68.5 & 91.3 & 6.4 \\
\hline \multirow{2}{*}{$\begin{array}{l}\text { Septembe } \\
\mathbf{r}\end{array}$} & I & 5.3 & 32.7 & 26.1 & 89.8 & 73.2 & 161.8 & 4.4 \\
\hline & II & 6.1 & 33.6 & 26.5 & 89.3 & 68.6 & 79.6 & 5.7 \\
\hline \multirow[t]{2}{*}{ October } & I & 5.8 & 32.7 & 25.8 & 90.1 & 71.3 & 63.4 & 5.8 \\
\hline & II & 9.1 & 32.5 & 24.8 & 91.3 & 65.6 & 130.8 & 6.5 \\
\hline \multirow{2}{*}{$\begin{array}{l}\text { Novembe } \\
\mathbf{r} \\
\end{array}$} & I & 7.2 & 32.0 & 22.8 & 90.2 & 55.7 & 56.0 & 6.7 \\
\hline & II & 8.0 & 31.1 & 19.2 & 90.3 & 50.1 & 0.6 & 6.5 \\
\hline \multirow[t]{2}{*}{ December } & I & 2.7 & 28.5 & 16.2 & 90.3 & 51.3 & 2.2 & 5.5 \\
\hline & II & 1.5 & 27.1 & 13.0 & 88.1 & 44.0 & 0.00 & 4.9 \\
\hline
\end{tabular}

Table.2 Correlation matrix of weather parameter on Red Rot disease in Sugarcane

\begin{tabular}{|c|c|c|c|c|c|c|c|}
\hline \multirow{3}{*}{$\begin{array}{l}\text { Incidence } \\
(\%)\end{array}$} & \multirow{3}{*}{$\begin{array}{l}\text { No. of } \\
\text { observation }\end{array}$} & \multicolumn{6}{|c|}{ Weather parameter } \\
\hline & & \multicolumn{2}{|c|}{ Temperature $\left({ }^{0} \mathrm{C}\right)$} & \multicolumn{2}{|c|}{ Relative humidity (\%) } & \multirow{2}{*}{$\begin{array}{l}\text { Rainfall } \\
(\mathrm{mm})\left(\mathrm{X}_{5}\right)\end{array}$} & \multirow{2}{*}{$\begin{array}{l}\text { Sunshine } \\
(\mathrm{hrs})\left(\mathrm{X}_{6}\right)\end{array}$} \\
\hline & & $\operatorname{Max} .\left(\mathrm{X}_{1}\right)$ & $\operatorname{Min}\left(X_{2}\right)$ & $\begin{array}{ll}7.00 & \text { hrs. } \\
\left(\mathrm{X}_{3}\right) & \end{array}$ & $\begin{array}{l}14.00 \mathrm{hrs} . \\
\left(\mathrm{X}_{4}\right)\end{array}$ & & \\
\hline Red rot $(Y)$ & 24 & 0.292 & $0.60 * *$ & $0.483^{*}$ & $0.531 * *$ & $0.722 * *$ & -0.362 \\
\hline
\end{tabular}

* - Significant at $5 \%$ probability

$* *$-Significant at $1 \%$ probability

Table.3 Multiple linear regression models for weather parameter on Red Rot incidence in sugarcane

\begin{tabular}{|c|c|c|c|c|c|c|c|c|c|}
\hline \multirow{3}{*}{$\begin{array}{l}\text { Incidence } \\
(\%)\end{array}$} & \multirow{3}{*}{$\begin{array}{l}\text { No. of } \\
\text { observation }\end{array}$} & \multirow{3}{*}{$\begin{array}{l}\text { Pure } \\
\text { constant }\end{array}$} & \multicolumn{6}{|c|}{ Weather parameter } & \multirow[t]{3}{*}{$\mathbf{R}^{2}$} \\
\hline & & & \multicolumn{2}{|c|}{ Temperature $\left({ }^{0} \mathrm{C}\right)$} & \multicolumn{2}{|c|}{$\begin{array}{l}\text { Relative humidity } \\
(\%)\end{array}$} & \multirow{2}{*}{$\begin{array}{l}\text { Rainfall } \\
(\mathrm{mm}) \\
\left(\mathrm{X}_{5}\right)\end{array}$} & \multirow[t]{2}{*}{$\begin{array}{l}\text { Sunshine } \\
(\mathrm{hrs})\left(\mathrm{X}_{6}\right)\end{array}$} & \\
\hline & & & $\begin{array}{l}\operatorname{Max} . \\
\left(X_{1}\right)\end{array}$ & $\begin{array}{l}\text { Min } \\
\left(\mathrm{X}_{2}\right)\end{array}$ & $\begin{array}{c}7.00 \mathrm{hrs} . \\
\left(\mathrm{X}_{3}\right)\end{array}$ & $\begin{array}{c}14.00 \\
\text { hrs. }\left(\mathrm{X}_{4}\right)\end{array}$ & & & \\
\hline Red rot $(\mathrm{Y})$ & 24 & -40.8668 & 0.6608 & -0.0293 & 0.3938 & -0.0376 & 0.0236 & -1.2976 & 0.7159 \\
\hline
\end{tabular}


The maximum disease incidence $(15.6 \%)$ was recorded during $2^{\text {nd }}$ fortnight of July when the maximum and minimum temperature was $33.3^{\circ} \mathrm{C}$ and $26.8^{0} \mathrm{C}$ with relative humidity at $07 \mathrm{hrs}$. and 14 hrs. was 88.1 per cent and 70.4 per cent, respectively with rainfall was 135.8 mm coupled with sunshine was $4.8 \mathrm{hrs}$. Whereas minimum (1.4\%) was recorded during $1^{\text {st }}$ fortnight of June when the maximum and minimum was $35.4^{\circ} \mathrm{C}$ and $25.2^{0} \mathrm{C}$, respectively and relative humidity at 07 hrs. (82.7\%) and $14 \mathrm{hrs} .(54.6 \%)$ with rainfall was $50.3 \mathrm{~mm}$ and sunshine hrs. being 7.5. The incidence of disease is appeared in $1^{\text {st }}$ fortnight of June which was lowest $(1.4 \%)$ among the moths of observations. Thereafter, gradually increasing trend was observed and its peak $(15.6 \%)$ was observed during $2^{\text {nd }}$ fortnight of July. Later on clear pattern was not seen, but during winter season disease severity was decreased as compared to rainy season. From the month of January to May the disease was not appeared on the crop during eleven years of study.

Correlation co-efficient of red rot incidence with weather parameters were worked out and presented in table 2, which indicated that the weather parameters exhibited positive correlation except sunshine. Minimum temperature, morning and afternoon relative humidity and rainfall showed significant positive correlation with disease development. There was not significant positive correlation of maximum temperature with red rot incidence indicating possible lesser disease incidence with lower day temperature. Minimum temperature and rainfall appeared to be most significant weather parameters contributing to the favourable condition for disease development.

Multiple regression equations involving weather parameters as independent variables and red rot incidence as depended variable were developed based on the data recorded during the study period. The regression equation has been presented in table $3 . R^{2}$ of the model was able to explain about 71 per cent variables in the incidence of red rot diseases involving maximum and minimum temperature, morning and afternoon relative humidity, rainfall and bright sunshine hours. The $\mathrm{R}^{2}$ value of the model was significant at 5 per cent level of significance. Neumeister, (2010) reported that a shift in temperature due to climate change will have an effect on some of biotic factors like diseases, insect pest and weeds in sugarcane production. Prateeksha and Sahu (2015) observed that hot and humid climate are conducive for the development of various diseases. In case of smut disease incidence the maximum temperature showed positive significant correlation (0.074) while, relative humidity showed negatively significant correlation (-0.683) and there was non-significant correlation obtained in case of rainfall, wind velocity and sunshine.

Multiple regression models for red rot disease

Red $\operatorname{rot}(\mathrm{Y})=-40.8668+0.6608 \mathrm{X}_{1^{-}}$ $0.0293 \mathrm{X}_{2}+0.3938 \mathrm{X}_{3}-0.0376 \mathrm{X}_{4}+0.0236 \mathrm{X}_{5^{-}}$ $1.2976 \mathrm{X}_{6}$

\section{References}

Gawade, D. B., Pawar, H. Gawande, J. and Vasekar, V. C. 2012. Antagonistic Effect of Trichoderma against Fusarium moniliforme the Causal agent of Sugarcane Wilt. American-Eurasian Journal of Agriculture \& Environment Science. 12 (9): 1236-1241.

Mehra Prateeksha and Sahu R. K., 2015. Correlation and Regression of Meteorological Factors with Sugarcane Smut Disease Cause by Sporisorium Scitaminea (Syn. Ustilago Scitaminea). The Bioscan 10 (4): 1691-1693.

Mohanraj, D. Padmanabhan, P. and 
Viswanathan, R. 2003. Biological control of sugarcane diseases. Biological control of crop Diseases, 161-177.

Neumeister, L: Crop protection: Anything can happen. PAN Asia Pacific. Penang, Malaysia 2010.

Ramasubramanium V, Sharma M. K., Walia S. S. 2006. Statistical Models for forewarning Incidence of major Pests of Paddy. Abstract Stat. Appl., 4:1-81.

Rott, P., R. A. Bailey, J. C. Comstock, B. J. Croft and S. Saumtally 2000. A guide to sugarcane diseases. Montepellier: CIRADISSCT, CIRAD Publication
Services.

Singh, R. K., Khan M. S., Singh, R. D. Pandey, K. Kumar S. and Lal, S. 2011. Analysis of genetic differentiation and phylogenetic relationships among sugarcane genotypes differing in response to red rot, Sugar Tech 13 (2): $137-144$.

Viswanathan, R. 2010. Plant diseases: Red rot of sugarcane. Anmol Publication Pvt. Ltd. New Delhi, 301 P.

Viswanathan, R. and Samiyappan, R. 1999. Red rot disease of sugarcane: major constraint for Indian Sugar Industry Sugarcane 5: 9-15.

\section{How to cite this article:}

Sudhir Paswan, Md. Minnatullah, Mahesh Kumar and Abdus Sattar. 2018. Impact of Weather Factors on Development of Red Rot Disease of Sugarcane Agro-Ecosystem. Int.J.Curr.Microbiol.App.Sci. 7(02): 8-12. doi: https://doi.org/10.20546/ijcmas.2018.702.002 